\title{
PALEOGENE CALCAREOUS NANNOPLANKTON EVOLUTION: THE FERTILITY LINK
}

AUBRY, Marie-Pierre, Laboratoire de Géologie du Quaternaire, CNRS-Luminy, Case 907, 13288 Marseille cedex 9, France, and Department of Geology and Geophysics, Woods Hole Oceanographic Institution, Woods Hole, Ma 02543, U.S.A.

Calcareous nannoplankton diversity varied greatly during the Paleogene. From extremely reduced values ( 10 species) in the early Paleocene (circa 66.4 to $66 \mathrm{Ma}$, age estimates from Berggren, Kent and Flynn, 1985) following the terminal Cretaceous extinctions, diversity increased progressively throughout the late Paleocene and early Eocene and reached a maximum ( 120 species) in the early middle Eocene (circa 52-48 Ma). This was followed by a step-like decrease until the early Oligocene (circa $35 \mathrm{Ma}$ ) when. minimal values ( 37 species) were reached once again. After a stable low during the remainder of the early Oligocene, a moderate, increase occurred near the early/late Oligocene boundary (circa $30 \mathrm{Ma}$ ).

Temperature has been regarded as the most important factor controlling the distribution of the calcareous nannoplankton following the characterisation of five temperature-controlled assemblages of living Coccolithophoridae in the Atlantic Ocean. Studies relative to variations in diversity in the calcareous nannoplankton throughout the Mesozoic and Cenozoic and among the extinct late Paleocene to Pliocene group Discoaster, and to changing biogeographic patterns during the Cenozoic have revealed an apparent relationship between composition of calcareous nannofossil assemblages and temperature as deduced from isotopic studies. This relationship, which is currently used to infer Paleogene climatic and oceanographic evolution from quantitative analyses of calcareous nannofossil assemblages, is however not a simple one as indicated by the fact that maximum diversity during the Paleogene (i.e., the early middle Eocene) did not occur during (but subsequently to) the warmest time (i.e., the latest Paleocene-carliest Eocene).

Diversity changes in the Paleogene calcareous nannoplankton are strikingly similar to diversity changes in the Paleogene planktonic foraminifera, which have been shown to reflect fluctuations in nutrient availibility as indicated by oxygen and carbon isotopes. The parallel evolution in the two groups thus suggests that trophic levels in the photic zone played an important role in the Paleogene diversification of the calcareous nannoplankton. In the present day ocean, the calcareous nannoplankton (Coccolithophoridae) dominate the phytoplankton under oligotrophic conditions and tropical waters are characterized by highly diversified associations with strong vertical specific stratification. Only few species occur under meso- and eutrophic conditions, and there is no vertical stratification. Extremely low diversity during the earliest Paleocene followed by increasing diversity through the Palcocene and carliest Eocene is interpreted as reflecting the change from an essentially mesotrophic to an oligotrophic ocean, increased rates of speciation resulting from niche partitioning occasioned by increased oligotrophy, leading to strong vertical stratification of species in the photic zone. Decrease in diversity from middle Eocene to early Oligocene reflects, on the other hand, progressive eutrophication of the ocean as a result of climatic deterioration. 